\title{
Morphological Stages of Bacillus subtilis Sporulation and Resistance to Fusidic Acid
}

\author{
By PETER FORTNAGEL \\ Abteilung Mikrobiologie, Fachbereich Biologie, Universität Hamburg, Germany \\ AND ELISABETH B. FREESE \\ Laboratory of Molecular Biology, NINCDS NIH, \\ Bethesda, Maryland 20014, U.S.A.
}

(Received 28 February 1977)

\begin{abstract}
During spore development of Bacillus subtilis both protein synthesis and sporulation become resistant to the antibiotic fusidic acid. This resistance develops at the time when asymmetric prespore septa are formed. Simultaneously ribosomes lose their ability to bind fusidic acid, as demonstrated by their affinity chromatography with the immobilized drug. Mutants resistant to fusidic acid during growth are oligosporogenous; their sporulation development is blocked before septum formation. These results indicate that normal ribosomes are needed for prespore septation sporulation; only after septation can protein synthesis be maintained, throughout the development period, by fusidate resistant ribosomes.
\end{abstract}

\section{INTRODUCTION .}

Massive sporulation of bacilli occurs after they have stopped growing in sporulation media. Subsequently, many metabolic changes occur which cause the transcription and translation of genes, some of which are specifically required for sporulation. Translation of the mRNA formed throughout the developmental period is accompanied by extensive RNA and protein turnover (for review, see Kornberg et al., 1968). The translation machinery for de novo protein synthesis originates in vegetative cells, although the continuing synthesis of ribosomal RNA suggests that new ribosomes are formed during the sporulation process (for review, see Cundliffe, 1972). Some translational functions are altered during spore formation of Bacillus subtilis. Whereas the ribosomal functions mediated by G-factor (EF-G) are sensitive to inhibition by the antibiotic fusidic acid in vegetative cells, they become resistant during spore formation (Fortnagel \& Bergmann, 1973; Fortnagel, 1973; Fortnagel et al., 1975). In vitro the drug inhibits the GTPase activity of $70 \mathrm{~S}$ ribosomeEF-G complexes isolated from growing cells, but does not inhibit those from sporulating cells. Apparently, normal ribosomal functions, including those identified by their sensitivity to fusidic acid, are required for the initiation of normal sporulation, because mutants already resistant to fusidic acid during growth are oligosporogenous (Fortnagel, 1973).

We report here the developmental stage at which the standard strain of B. subtilis becomes resistant to fusidic acid and at which stage fusidic acid resistant mutants are blocked in their development.

\section{METHODS}

Bacterial strains. Derivatives of the transformable Marburg strain of Bacillus subtilis were used throughout. Our standard strain (600I5) required tryptophan (indole) and methionine for growth (Freese \& Fortnagel, 1967). To isolate spontaneous fusidic acid resistant mutants, strain 60015 was grown in nutrient sporulation medium (NSM; Schaeffer et al., 1965) from a single colony. Approximately $10^{8}$ bacteria $\mathrm{ml}^{-1}$ were 
inoculated onto plates containing $33 \mathrm{~g}$ Difco tryptose blood agar base $1^{-1}$ (TBAB plates). Sodium fusidate ( $50 \mu \mathrm{l}$ of $\mathrm{I} \mathrm{mM}$ filter-sterilized solution) was pipetted into a well stamped into the agar of each plate. After 3 days incubation at $37^{\circ} \mathrm{C}$ small colonies developed in the inhibition zone. Only one resistant mutant was picked from each plate to ensure that distinct mutants were isolated. Sporulating revertants of these mutants were obtained after treatment with I $\mu \mathrm{g} N$-methyl- $N^{\prime}$-nitro- $N$-nitrosoguanidine $\mathrm{ml}^{-1}$ in $0.25 \mathrm{M}$-phosphate buffer pH 6.5 for $30 \mathrm{~min}$ at $37^{\circ} \mathrm{C}$ (Freese \& Fortnagel, 1967). The treated samples were diluted into NSM, grown overnight at $37^{\circ} \mathrm{C}$, heated for $15 \mathrm{~min}$ at $75^{\circ} \mathrm{C}$ to inactivate vegetative cells, and plated on TBAB plates. Revertants were detected by their brown colony appearance after 3 days at $37^{\circ} \mathrm{C}$ compared with the pale colonies of fusidic acid resistant mutants. To obtain distinct revertants, only one revertant colony was isolated from each culture.

Growth conditions. Bacteria were grown in NSM at $37^{\circ} \mathrm{C}$ in Erlenmeyer flasks in a reciprocal water-bath operating at 120 strokes $\mathrm{min}^{-1}$. The flasks were filled to not more than one-fifth of their volume to allow optimum aeration. Growth was followed by measuring the absorbance of the cultures in an Eppendorf photometer equipped with a monochromatic filter of $578 \mathrm{~nm}$. Cell titres were determined after dilution in O. I M-phosphate buffer $\mathrm{pH} 6.5$, containing $1 \mathrm{mM}-\mathrm{MgCl}_{2}$, and plating on TBAB plates. Spore titres were determined after heating the dilutions for $15 \mathrm{~min}$ at $75^{\circ} \mathrm{C}$. The notation $T_{n}$, where $n$ is the time in hours after exponential growth ceased, is used to indicate the sporulation stage of the culture.

Fusidic acid inhibition. Minimum inhibitory concentrations (m.i.c.) were determined by the agar diffusion method (Sherwood, Falco \& de Beer, 1944). Growth and inhibition of sporulation were measured in NSM.

Amino acid incorporation. At different growth stages in NSM $0.5 \mathrm{ml}$ culture samples were transferred to test tubes (20 mm diam.) containing $0 \cdot 1 \mu \mathrm{Ci}$ uniformly ${ }^{14} \mathrm{C}$-labelled protein hydrolysate $\left(57 \mathrm{mCi} \mathrm{matom}^{-1}\right.$ ) which gave a final concentration of $0.3 \times 10^{-3} \mathrm{M}$; fusidic acid or chloramphenicol were present at final concentrations of $5 \times 10^{-6} \mathrm{M}$ or $2.5 \times 10^{-4} \mathrm{M}$ respectively. The samples were shaken at $37^{\circ} \mathrm{C}$ for $30 \mathrm{~min}$; $\mathrm{I} \mathrm{ml}$ ice-cold $10 \%(\mathrm{w} / \mathrm{v})$ trichloroacetic acid was added and, after standing for $30 \mathrm{~min}$ in ice, the samples were collected on membrane filters (Sartorius, type I I I06, $0.45 \mu \mathrm{m}$ ) and washed five times with approximately $5 \mathrm{ml}$ ice-cold $5 \%$ trichloroacetic acid. The filters were dissolved in $10 \mathrm{ml}$ Bray's solution (Bray, 1960) and the radioactivity was determined in a Beckman 230 scintillation spectrometer.

Affinity binding of ribosomes to immobilized fusidic acid. Fusidic acid was coupled to Sepharose 6B via the spacer 1,4-butanediol-diglycidyl ether (Porath, 1974). A column $(0.5 \times 2.5 \mathrm{~cm})$ was filled with the immobilized drug and equilibrated with buffer containing: $10 \mathrm{mM}-\mathrm{Tris} / \mathrm{HCl}$, $10 \mathrm{~mm}-\mathrm{magnesium}$ acetate,

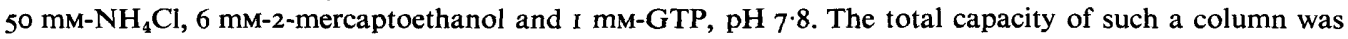
approximately $5 \mathrm{mg}$ ribosomes per $\mathrm{ml}$ packed gel.

Bacteria were grown in NSM in the presence of $\left[2-^{14} \mathrm{C}\right]$ uracil $\left(0 \cdot 15 \mu \mathrm{Ci} \mathrm{ml}{ }^{-1} ; 10^{-4} \mathrm{M}\right)$ for three generations. At different times of growth and sporulation, samples were taken and harvested at $0{ }^{\circ} \mathrm{C}$ by centrifuging for $5 \mathrm{~min}$ at $48000 \mathrm{~g}$. Bacteria were washed twice in the above buffer; after resuspension in this buffer they were lysed in a French press and then centrifuged for $5 \mathrm{~min}$ at $48000 \mathrm{~g}$. The supernatant fraction was used as the crude cell extract. This extract, containing less than one-tenth of the total column capacity for ribosomes, was immediately added to the fusidate column at $25^{\circ} \mathrm{C}$ to allow optimum complex formation. After I min the temperature was lowered and maintained at $0{ }^{\circ} \mathrm{C}$. The column was washed with the above buffer lacking GTP until no further radioactive or ultraviolet light-adsorbing material was eluted. This washing procedure was completed in less than $5 \mathrm{~min}$. Thereafter ribosomes were eluted with buffer containing $250 \mathrm{~mm}-$ $\mathrm{NH}_{4} \mathrm{Cl}$. The fraction of the total $\left[{ }^{14} \mathrm{C}\right]$ uracil label in this eluate is a direct measure of the complexforming capacity of ribosomes with fusidic acid in the presence of GTP (Fortnagel, 1977).

Electron microscopy. In order to determine the morphological stage at which fusidic acid resistance occurred, samples were taken from the original culture at different times during growth and the developmental period. They were fixed with glutaraldehyde, post-fixed with osmium tetroxide, and stained with uranyl acetate and lead citrate as described previously (Freese, Cooney \& Freese, 1975). For each sample, 200 to 300 longitudinally sectioned cells were analysed with a Philips 201 electron microscope. The results were statistically evaluated as described by Freese et al. (1975). The engulfment substages were defined (see Fig. 3) so that they agree with the original definitions used for mutants by Ryter, Schaeffer \& Ionesco (1966) and the recent review of Piggott \& Coote (1976), rather than the definitions used by others.

\section{RESULTS}

\section{Influence of fusidic acid on growth and sporulation}

Growth of the standard strain B. subtilis 60015 in nutrient sporulation medium was inhibited by fusidic acid concentrations of $50 \mathrm{~nm}$ or higher. Similarly, the formation of heatresistant spores was inhibited if fusidic acid was added during exponential growth or within 


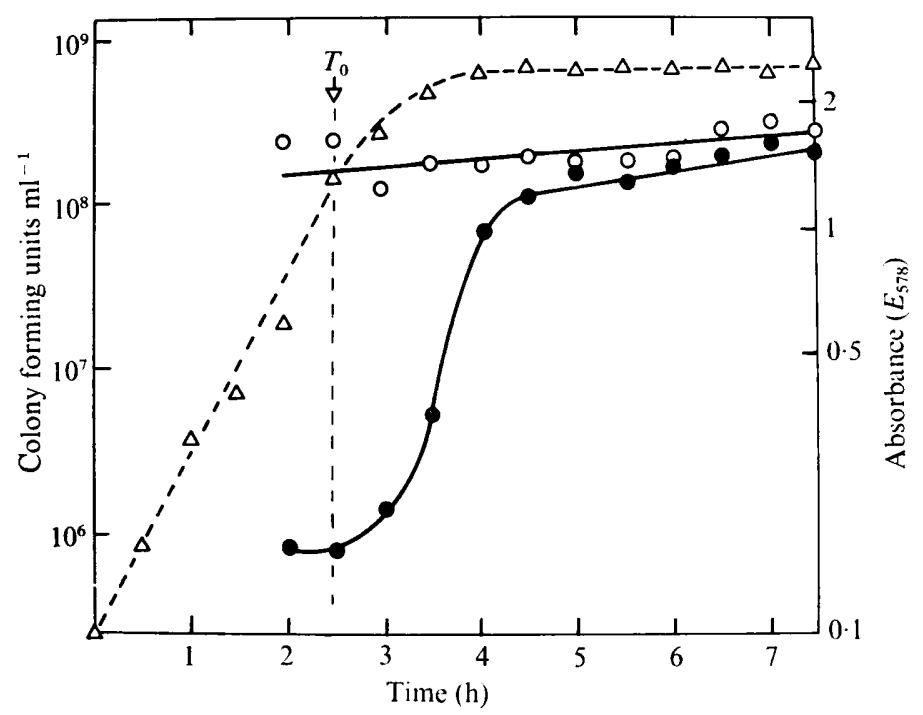

Fig. I. Influence of fusidic acid on growth and sporulation of Bacillus subtilis. The standard strain 60015 was grown in NSM. Growth was followed by measuring $E_{578}(\triangle)$. At different times, I ml samples were transferred to test tubes containing $5 \mathrm{nmol}$ fusidic acid. The tubes were shaken at $37^{\circ} \mathrm{C}$ and the titres of both total colony forming units $(V=$ vegetative cells plus spores; $O)$ and heat-resistant colony forming units $(S=$ spores; $O)$ were determined $20 \mathrm{~h}$ after the beginning of the experiment.

the first hour after exponential growth ceased, i.e. up to $T_{1}$ (Fig. 1). Subsequently, fusidic acid sensitivity decreased; spores were produced at the normal frequency within the next Io $\mathrm{h}$ even in the presence of $5 \mu \mathrm{M}$-fusidate, provided that this was added after $T_{2}$.

The rate of incorporation of a ${ }^{14} \mathrm{C}$-labelled amino acid mixture into acid-precipitable material decreased rapidly after $T_{0}$ in the untreated control culture (Fig. $2 a$ ); it reached a minimum value at $T_{0.5}$ and remained low during the following sporulation period. Both fusidic acid and chloramphenicol inhibited amino acid incorporation during growth. The chloramphenicol inhibition continued beyond $T_{1}$, whereas the incorporation in the presence of fusidic acid increased after $T_{1}$ and reached the level of incorporation of the untreated culture at $T_{2 \cdot 5}$; thus protein synthesis was then completely resistant to a Ioo-fold excess of fusidate. The appearance of sporulation resistance paralleled the increasing resistance of the amino acid incorporation (Fig. $2 b$ ).

That the activity of fusidic acid did not decrease during this prolonged treatment was shown by the following experiment. The standard strain (60015) was grown in NSM to $T_{2}$ and then fusidate was added to a final concentration of $\mathrm{I} \mu \mathrm{M}$. Immediately, and at intervals up to $24 \mathrm{~h}$, samples were taken and the biological inhibitory activity of the drugcontaining solution was measured against exponentially growing $B$. subtilis by the agar diffusion method. No inactivation of the drug could be demonstrated. This method could detect a $10 \%$ inactivation, as was shown by dilution of the original fusidate-containing culture.

\section{Affinity binding of ribosomes to immobilized fusidic acid}

Fusidic acid forms a stable complex with 70 S ribosomes (EF-G and GDP) even when the drug is covalently bound to Sepharose 6B via the spacer molecule I,4-butanediol-diglycidyl ether (Fortnagel, 1977). Thus ribosomes from the extract of sensitive vegetative B. subtilis were quantitatively retained by fusidate columns in the presence of I mM-GTP and $50 \mathrm{~mm}$ $\mathrm{NH}_{4} \mathrm{Cl}$. They could be eluted with $250 \mathrm{~mm}-\mathrm{NH}_{4} \mathrm{Cl}$. Binding did not occur when cell extracts of fusidate resistant mutants (Table I) were used. 

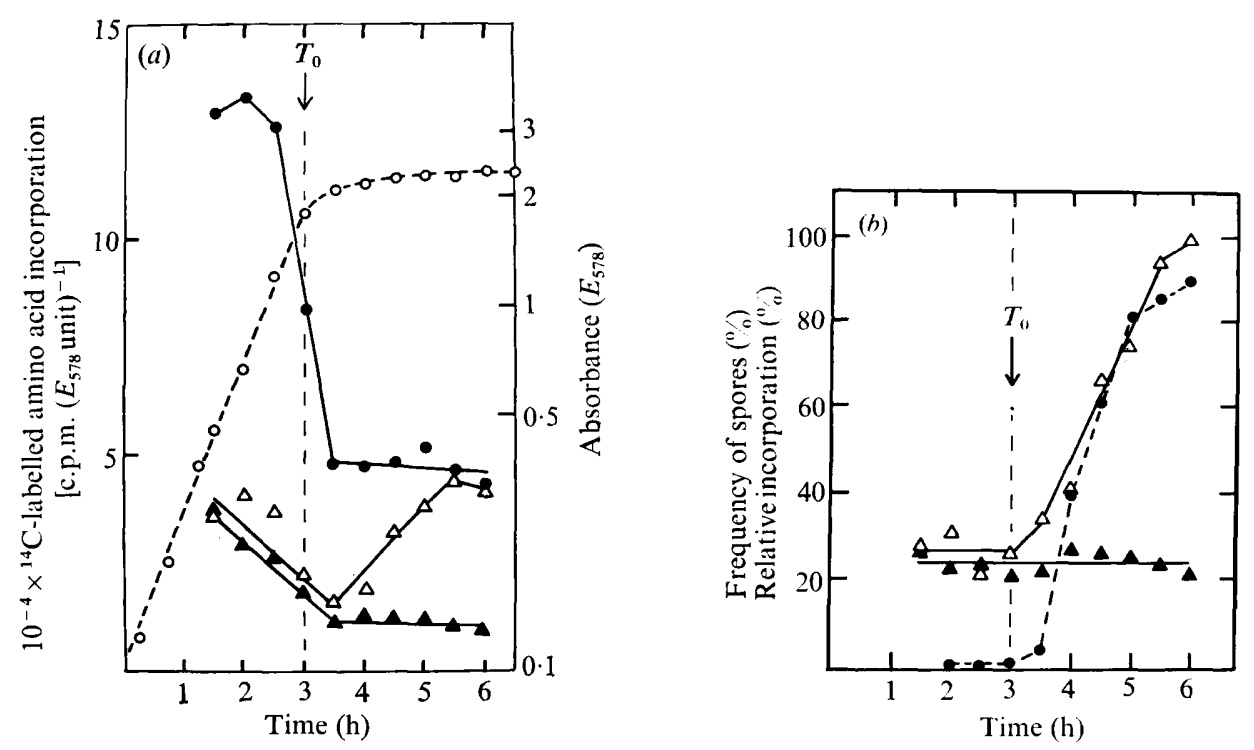

Fig. 2. (a) Rate of incorporation of ${ }^{14} \mathrm{C}$-labelled amino acid into acid-precipitable material during growth and sporulation. Strain 60015 was grown in NSM. At different times samples were taken and incubated for $30 \mathrm{~min}$ with ${ }^{14} \mathrm{C}$-labelled amino acids (protein hydrolysate) alone (O) or with added $5 \times 10^{-6} \mathrm{M}$-fusidic acid $(\triangle)$ or $2.5 \times 10^{-4} \mathrm{M}$-chloramphenicol $(\Delta)$. The acid-precipitable radioactivity (c.p.m.) was determined and plotted per $E_{578}$ unit of the culture [c.p.m. $\left(E_{578}\right.$ unit) ${ }^{-1}$ ]. Growth was followed by measuring $E_{578}(\bigcirc)$.

(b) Relative rate of incorporation of ${ }^{14} \mathrm{C}$-labelled amino acid. The values are expressed as the ratio of the incorporation in the presence of either fusidic acid $(\triangle)$ or chloramphenicol $(\Delta)$ to the incorporation without inhibitors. Spore formation in the presence of fusidic acid was measured as in Fig. $\mathrm{I}$; the sporulation frequency $(S / V ; O)$ is equal to the titre of heat-resistant colony forming units divided by the titre of total colony forming units.

If the development of resistance of sporulation and of amino acid incorporation into protein after $T_{2}$ occurred as a result of a change in the site of the ribosome-EF-G complexes to which fusidate adsorbs, one would expect that binding of the drug would disappear during sporulation. This is actually the case (Fig. 3). During growth and up to $T_{1}$, the affinity binding of $\left[2-{ }^{14} \mathrm{C}\right]$ uracil-labelled material reached $80 \%$ of the total amount applied. Thereafter, the bound fraction decreased; at $T_{2}$, less than $20 \%$ of the label was bound and this low binding remained constant for later times. This residual binding may represent unmodified ribosomes. Non-specific adsorption to the modified Sepharose can be ruled out; no binding was found in the presence of $50 \mathrm{mM}_{-} \mathrm{NH}_{4}{ }^{+}$with deoxycholic acid bound via the above spacer to Sepharose 6B. The loss of binding capacity coincided with the development of resistance during sporulation (Fig. 3).

\section{Correlation of fusidic acid resistance and morphological stages of development}

To determine whether the development of resistance to fusidate corresponded to a certain morphological stage of development, both properties were measured in the same culture (Fig. 3). The sporulation stages are defined in the legend to Fig. 3. An excellent agreement was found between resistance of sporulation and stage IIa $^{+}$of development (IIa ${ }^{+}$indicates that cells have reached stage IIa or any later stage); apparently cells became resistant to fusidate as soon as they had formed the prespore septum. The midpoints $(50 \%)$ of the curves for the development of sporulation resistance and stage $\mathrm{IIa}^{+}$both occurred at $T_{1 \cdot 3}$; they coincided with the midpoints of the curves for the increase in resistance of amino acid incorporation (Fig. $2 b$ ) and the decrease in binding of $\left[{ }^{14} \mathrm{C}\right]$ uracil-labelled 




Fig. 3. Comparison of development of fusidate resistance with morphological stages of sporulation. , Sporulation frequency $(S / V)$ in the presence of fusidic acid, determined as in Fig. $2(b)$. $\square$, Percentage of RNA ([14C]uracil-labelled material) bound to immobilized fusidic acid in the presence of $50 \mathrm{mM}-\mathrm{NH}_{4}+$. Sporulation stages are defined as: $0-\mathrm{I}$, cells without prespore septa $(\Delta)$; IIa, cells with a developing up to a finished asymmetric septum ( $\triangle$ ); IIb, cells with prespore membrane curved up to a $50 \%$ engulfment $(\nabla)$; IIc, cells with $50 \%$ prespore membrane engulfment up to almost complete enclosure of the prespore ( $\nabla)$; III, cells in which the prespore is completely engulfed in the double membrane $(O)$. + signifies inclusion of all cells at later stages of development, e.g. IIa ${ }^{+}$includes all cells with a developing asymmetric septum or at a later morphological stage.

material to immobilized fusidic acid (Fig. 3). When fusidate was added before $T_{0.5}$ no prespore septa developed and no sporulation took place. The minimum inhibitory concentration of $50 \mathrm{~nm}$-fusidic acid then led to the formation of long cell filaments.

\section{Fusidic acid resistant mutants}

Two hundred distinct spontaneous fusidate resistant mutants (gene symbol fus) were isolated. These mutants were oligosporogenous as is shown for five representatives in Table $I$. They grew at the normal rate and to the normal cell titre as judged by the absorbance of the cultures. Thus their growth properties were indistinguishable from the sporulating standard strain. Revertants with normal ability to sporulate were isolated from the individual fus mutants after nitrosoguanidine treatment. These revertants were all sensitive to fusidic acid.

When the five fus mutants of Table I were examined with an electron microscope at $T_{5}, 99 \%$ of the cells had not reached stage IIa of development, i.e. no prespore septa were visible. In contrast $78 \%$ of the cells from the control culture of the standard strain 60015 had proceeded at least to stage IIa and mostly beyond. Although the mutants did not sporulate, wall synthesis must have continued at least for a while, since the mutant cells at $T_{5}$ had much thicker walls than exponentially growing cells or sporulating $B$. subtilis cells at $T_{5}$.

That the fus mutants did not destroy the added fusidate was shown by the agar diffusion method described for the standard strain above. 
Table I. Growth and sporulation properties of fusidic acid resistant mutants of B. subtilis

\begin{tabular}{|c|c|c|}
\hline $\begin{array}{l}\text { Strain } \\
60015\end{array}$ & $\begin{array}{l}\text { Parent strain } \\
\text { standard strain }\end{array}$ & $\begin{array}{c}\text { Isolated } \\
\text { phenotype }\end{array}$ \\
\hline $\begin{array}{l}70044 \\
44 r_{7} \\
44 r_{5}\end{array}$ & $\begin{array}{l}60015 \\
70044 \\
70044\end{array}$ & $\begin{array}{l}\text { Fus } \\
\text { Spo }^{+} \\
\text {Spo }^{+}\end{array}$ \\
\hline $\begin{array}{l}70045 \\
45 \mathrm{r}_{1} \\
45 \mathrm{r}_{2} \\
45 \mathrm{r}_{3}\end{array}$ & $\begin{array}{l}60015 \\
70045 \\
70045 \\
70045\end{array}$ & $\begin{array}{l}\text { Fus } \\
\text { Spo }^{+} \\
\text {Spo }^{+} \\
\text {Spo }^{+}\end{array}$ \\
\hline 70046 & 60015 & Fus \\
\hline $\begin{array}{l}70047 \\
47 r_{1} \\
47 r_{2}\end{array}$ & $\begin{array}{l}60015 \\
70047 \\
70047\end{array}$ & $\begin{array}{l}\text { Fus } \\
\text { Spo }^{+} \\
\text {Spo }^{+}\end{array}$ \\
\hline $\begin{array}{l}70048 \\
48 r_{1} \\
48 r_{2} \\
48 r_{3} \\
48 r_{4} \\
48 r_{5}\end{array}$ & $\begin{array}{l}60015 \\
70048 \\
70048 \\
70048 \\
70048 \\
70048\end{array}$ & $\begin{array}{l}\text { Fus } \\
\text { Spo }^{+} \\
\text {Spo }^{+} \\
\mathbf{S p o}^{+} \\
\text {Spo }^{+} \\
\text {Spo }^{+}\end{array}$ \\
\hline
\end{tabular}

$\begin{array}{cc}\text { M.i.c. of } \\ \text { Treatment } & \begin{array}{c}\text { fusidic acid } \\ \text { (M) }\end{array} \\ & 5 \times 10^{-8} \\ \text { spontaneous } & 6 \times 10^{-4} \\ \text { NTG } & 4 \times 10^{-7} \\ \text { NTG } & 5 \times 10^{-8} \\ \text { spontaneous } & 9 \times 10^{-5} \\ \text { NTG } & 5 \times 10^{-8} \\ \text { NTG } & 4 \times 10^{-8} \\ \text { NTG } & 1 \times 10^{-8} \\ \text { spontaneous } & 2 \times 10^{-5} \\ \text { spontaneous } & 2 \times 10^{-5} \\ \text { NTG } & 1 \times 10^{-7} \\ \text { NTG } & 5 \times 10^{-8} \\ & 8 \times 10^{-5} \\ \text { spontaneous } & 3 \times 10^{-8} \\ \text { NTG } & 7 \times 10^{-8} \\ \text { NTG } & 1 \times 10^{-7} \\ \text { NTG } & 3 \times 10^{-7} \\ \text { NTG } & 5 \times 10^{-8} \\ \text { NTG } & \end{array}$

$\begin{array}{cc}\begin{array}{c}\text { Total titre } \\ \text { after } 24 \mathrm{~h} \\ \text { in NSM } \\ \text { (c.f.u. } \mathrm{ml}^{-1} \text { ) }\end{array} & \begin{array}{c}\text { Frequency of } \\ \text { spores after } 24 \mathrm{~h} \\ \text { in NSM }\end{array} \\ 2.8 \times 10^{8} & 8.8 \times 10^{-1} \\ 4.7 \times 10^{8} & 1.2 \times 10^{-4} \\ & 5.7 \times 10^{-1} \\ & 6.0 \times 10^{-1} \\ 2.3 \times 10^{8} & 6.5 \times 10^{-4} \\ & 7.0 \times 10^{-1} \\ & 7.2 \times 10^{-1} \\ & 4.5 \times 10^{-1} \\ 3.0 \times 10^{8} & 9.2 \times 10^{-3} \\ 2.9 \times 10^{8} & 1.5 \times 10^{-3} \\ & 7.0 \times 10^{-3} \\ & 4.2 \times 10^{-3} \\ & 2.3 \times 10^{-3} \\ 1.5 \times 10^{8} & 9.2 \times 10^{-1} \\ & 7.2 \times 10^{-1} \\ & 1.0 \times 10^{-1} \\ & 4.4 \times 10^{-1} \\ & 6.5 \times 10^{-1}\end{array}$

NTG, $N$-Methyl- $N$ '-nitro- $N$-nitrosoguanidine. 


\section{DISCUSSION}

The ability of the standard strain of Bacillus subtilis to form spores in nutrient sporulation medium changes from being sensitive to fusidate to being resistant at about $T_{1 \cdot 5}$, at the same time as the asymmetric prespore septum is formed. In contrast, sporulation remains sensitive to chloramphenicol and other antibiotics (Sterlini \& Mandelstam, 1969) throughout development.

The observed transition could arise from several cellular changes. (i) A modification of the cell membrane composition or structure might exclude fusidate from further entry or transport into the cells. Such a change was, for example, found in fusidate resistant mutants of Staphylococcus aureus (Chopra, I976). Since we did not have radioactively labelled fusidic acid, this possibility could not be examined here. (ii) Fusidate could be enzymically modified or degraded and thus inactivated. Our measurements, which allow detection of $10 \%$ degradation, have excluded this possibility. (iii) Resistance could occur by a change of the protein synthetic machinery, such as an alteration of ribosomes or of the translocation factor EF-G which is a known site of fusidate attack (Cundliffe, I972).

The GTPase activity of purified ribosomes can be measured uncoupled from protein synthesis; it depends on the addition of EF-G. Irrespective of the source of EF-G, this reaction is sensitive to fusidate if the ribosomes are isolated from vegetative cells of the standard strain, but it is resistant if the ribosomes are isolated from sporulating cells after $T_{2}$ (Fortnagel, 1977). The GTPase activity is also resistant to fusidate if EF-Gribosomal complexes are isolated from vegetative cells of fusidate resistant mutants (Fortnagel \& Bergmann, 1973).

In the presence of GTP, the affinity binding of crude ribosomes containing the translocation factor EF-G to immobilized fusidic acid greatly decreases between $T_{0.5}$ and $T_{1.5}$ (Fortnagel, 1977); at the same time, both the EF-G dependent GTPase activity (in vitro) and the amino acid incorporation decline. These events clearly demonstrate a ribosomal change early in sporulation. It remains an intriguing possibility that this change may be actually necessary for sporulation.

Formation of the asymmetric prespore septum and the development of resistance to fusidate occur simultaneously. Apparently, normal ribosomes are needed for prespore septation. Thereafter, the altered ribosomes suffice (or are needed?) to maintain protein synthesis during the continuing development. This conclusion agrees with the finding that fus mutants, which are already resistant to fusidate during exponential growth, are blocked in their sporulation development before the prespore septum is formed. But it is not known whether the asymmetric septation and the ribosomal changes are causally related or are only by chance correlated in time. The results certainly show that the development of fusidate resistance does not depend on the engulfment of the forespore; it occurs earlier.

Although these findings clearly demonstrate a change of ribosomes early in sporulation, we cannot yet exclude the possibility that other changes might occur which influence fusidate sensitivity of $B$. subtilis. For example, a modification of the cell membrane composition or structure might block the further uptake of fusidate during sporulation.

We thank Dr Ernst Freese for helpful discussions.

\section{REFERENCES}

Bray, G. A. (1960). A simple efficient liquid scintillator for counting aqueous solutions in a liquid scintillation counter. Analytical Biochemistry r, 279-285.

Chopra, I. (1976). Mechanisms of resistance to fusidic acid in Staphylococcus aureus. Journal of General Microbiology 96, 229-238.
Cundliffe, E. (1972). The mode of action of fusidic acid. Biochemical and Biophysical Research Communications 46, I 794-180I.

FortNAGEL, P. (1973). Ribosomal alteration during sporulation of Bacillus subtilis. Colloques internationaux du Centre national de la recherche scientifique 227, I13-I 14 . 
ForTNAGEL, P. (1977). Affinity chromatographic analysis of ribosomal changes during sporulation of B. subtilis. In Spore Research 1976. Edited by A. N. Barker, J. Wolf, D. J. Ellar, G. J. Dring and G. W. Gould. London: Academic Press (in the:Press).

FortNagel, P. \& BergmanN, R. (1973). Alteration of the ribosomal fraction of Bacillus subtilis during sporulation. Biochimica et biophysica acta 299, 136-141.

Fortnagel, P., Bergmann, R., Hafemann, B. \& LENGELSEN, C., (1975). Structural and functional alteration of Bacillus subtilis ribosomes. In Spores VI, pp. 301-306. Edited by P. Gerhardt, H. L. Sadoff and R. N. Costillow. Washington D.C.: American Society for Microbiology.

FreEse, E. \& FortNAGeL, P. (1967). Analysis of sporulation mutants. I. Response of uracil incorporation to carbon sources and other mutant properties. Journal of Bacteriology 94, 19571969.

Freese, E. B., CoONey, P. \& Freese, E. (I975). Conditions controlling commitment of differentiation in Bacillus subtilis. Proceedings of the National Academy of Sciences of the United States of America 72, 4037-404I.

KornberG, A., Spudich, J. A., Nelson, D. L. \&
DeUTSCHER, M. P. (1968). Origin of proteins in sporulation. Annual Review of Biochemistry 37, $5 \mathrm{I}-78$.

PIGGot, P. J. \& CoOTE, J. G. (1976). Genetic aspects of bacterial endospore formation. Bacteriological Reviews 40, 908-962.

PORATH, J. (1974). General methods and coupling procedures. Methods in Enzymology 34, 13-30.

Ryter, A., SChaeffer, P. \& IONeSCo, H. (I966). Classification cytologique, par leur stade de blocage, des mutants de sporulation de Bacillus subtilis Marburg. Annales de l'Institut Pasteur IIO, 305-315.

SChaefFer, P., IONesco, H., Ryter, A. \& Balassa, G. (I965). La sporulation de Bacillus subtilis: étude génétique et physiologique. Colloques internationaux du Centre national de la recherche scientifique 124, 553-563.

Sherwood, M. B., FAlCo, E. A. \& De Beer, E. J. (1944). Factors influencing the speed and accuracy of a simple quantitative assay method of testing antibiotic substances. Journal of Bacteriology 47, 424.

Steruini, J. M. \& Mandelstam, J. (I969). Commitment to sporulation in Bacillus subtilis and its relationship to development of actinomycin resistance. Biochemical Journal 113, 29-37. 